\title{
Whanganui: respectful relationships at the heart of our city - a story from New Zealand
}

\author{
Jenny Saywood
}

\section{Origins of the project}

Restorative Justice in Whanganui (New Zealand, NZ) began in 1999 as a result of a public meeting called for by the presiding District Court Judge at that time, Andrew Becroft. The meeting was to talk about Youth Justice. In New Zealand at this time, young offenders appearing in Youth Court were given the opportunity to attend a Family Group Conference. Although not purely restorative, these conferences were an attempt to allow the victim the chance to discuss the impact of offence on them and for the offender to listen, understand and express remorse. New Zealand was a pioneer in establishing this process. During the public meeting, a suggestion was made to trial a similar process with adults in the District Court as was happening in a few places in New Zealand at this time. Judge Becroft offered out the challenge to the audience and asked those interested to meet to discuss and progress this idea. Two of the present Trust were part of this group.

Six months later the Whanganui Restorative Justice Trust was formed. At that time it came under the umbrella of the Crime Prevention Unit of Ministry of Justice and a District Council steering group called Safer Whanganui. In the early days restorative justice was offered for low level offending but as the process became understood and trusted, more serious offences were included. The success of the restorative justice initiative was due in part to the initial support of Judge Becroft and key stake holders - the local Police Chief, Department of Child Youth and Family, Probation Service and Prisoners Aid. Judge Andrew Becroft later became the Patron of the Trust.

Several years later the Ministry of Justice piloted restorative justice in selected cities around New Zealand, and as a consequence of these pilots the Ministry of Justice began funding and overseeing the provider groups. In 2003 the Sentencing Act was amended to include restorative justice as an option for judges; and several years later, legislation came into force to make it mandatory for

* Jenny Saywood is a previous Service Manager in the Department of Corrections, New Zealand, and founder and Chair of WRP Trust at Whanganui.

Thank you to Shelly Harkness, who was the first coordinator of the Restorative Practices Trust and was instrumental in developing training in our early days. She works part time for the Trust as a Facilitator.

Contact author: jenny.saywood@restorativepracticeswhanganui.co.nz.

Whanganui Restorative City: https://restorativepracticeswhanganui.co.nz/. 
judges to refer to restorative justice. The Ministry of Justice developed the first 'Restorative justice: Best practice in New Zealand' document in 2004 followed by an update in 2017 (Ministry of Justice, 2017).

\section{Theoretical and conceptual basis}

After many years of overseeing restorative justice, the Trust could see that the underlying restorative philosophy had relevance in all aspects of community life and did not need to be confined to the criminal justice system. Schools were the obvious first choice. In order to explore this idea, it began by offering support to local schools and formed a relationship with the regional office of the Ministry of Education. In 2009, the Ministry of Education had held a 'Taumata Whanonga Behaviour Summit' and developed a 'Positive Behaviour for Learning' (PB4L) programme incorporating restorative practice principles. In their 'Overview' document the Ministry of Education stated that PB4L will help "to develop inclusive learning environments" (Ministry of Education, 2015). Hearing about Margaret Thorsborne, an Australian expert in restorative training for school teachers, they enlisted her help in providing workshops for people interested in the restorative approach. ${ }^{1}$

In 2012 the Whanganui Restorative Practices Trust was formed to sit alongside the Restorative Justice Service. The Trust was tasked with introducing the idea and encouraging the use of the restorative approach within organisations and workplaces. It was fortunate to make some very useful connections in those early days. Paul Nixon, brother of Estelle MacDonald, Director of Hull Centre of Restorative Practice, who had been developing restorative schools in Hull, UK, was in New Zealand as the Chief Social Worker. ${ }^{2}$ Paul was instrumental in providing some initial funding and lending us one of his staff to chair our Whanganui Restorative City Advisory Group, set up to provide support and advice to the Trust. This group is now chaired by a former local Member of Parliament, Chester Borrows.

Paul Nixon also introduced us to Jennifer Llewellyn a Professor of Law at Dalhousie University in Nova Scotia, Canada. She had been involved in restorative justice research for many years at that time and was keen to offer advice and encouragement. Jennifer has visited Whanganui several times, once bringing a delegation from Halifax, Nova Scotia, to attend and present at a Restorative City Conference we held in Whanganui. This visit was very useful in raising the profile of restorative practice and the international connections.

Jennifer also introduced the Trust to the idea of relational theory (Downie \& Llewellyn, 2012) which holds at its heart the idea that the human self is fundamentally constituted in terms of its relation to others. This theory helps underpin and explain restorative justice and at the same time provides a theoretical frame-

1 Margaret Thorsborne \& Associates: https://www.thorsborne.com.au/.

2 Hull Centre for Restorative Practice: www.hullcentreforrestorativepractice.co.uk. 
work. Connecting with Jennifer has been a catalyst to the Trust's re-thinking of the direction it should take.

The Trust wanted to dispel the idea, prevalent at the time, that the restorative approach was only applied when there was conflict or harm done. It wanted to promote the idea of a community that holds at its core, respect, care and concern for each other through respectful relationships. To build social capital in order to produce a resilient community that could manage diversity and conflict within it, and one that when harm is done, the restorative healing processes would be second nature or the default position.

A vision was created 'Towards a Restorative City: creating the environment for Whanganui people to thrive and succeed together through respectful relationships'. It was realised that if the Trust were going to talk about working towards a Restorative City it was important that it had the support of both the District Council and the Maori community of Whanganui (Iwi). John Maihi, a Maori elder (Kaumatua) was approached to translate our vision into Te Reo (Maori language) which is 'Honoa ki a Rongo ki Whanganui', Rongo being the God of Peace.

The Trust also met with the then Mayor and the District Council Chief Executive and they both agreed to work with and promote restorative practice within the Council and in the city. Later, a new Mayor and Chief Executive have seen the relationship grow, culminating in the District Councillors adopting a restorative approach in their Code of Conduct (Whanganui District Council, 2017) and the Executive Team undertaking restorative awareness training.

\section{Operationalisation and ongoing processes}

The growth of understanding and practice of the restorative approach has taken the Trust and its facilitators in many directions. Requests for restorative conferences have come from widely diverse organisations and citizens of Whanganui. Facilitators are building case studies, some of which can be accessed via the Restorative Practices Whanganui website.

One early request came from the then Mayor who understood the need for a relational rather than regulatory, and punitive, approach to address the growing tension in a pensioner housing complex managed by the Council. All steps the Council Housing staff had taken to address the tension had not resolved it, and they were at the final step of terminating the Pensioner's tenancy who was seen to be the 'trouble maker'. Taking a restorative approach helped all the Pensioners and the Council staff involved to understand the reasons for the tension, which was not solely down to that one Pensioner. The Pensioner was able to remain in their home.

Facilitators have worked with Council Animal Rangers to assist with common neighbour issues over barking or escaping dogs. Again, Council recognised the need to work relationally with the long term aim of empowering neighbours to respectfully resolve their own issues and only contact Council if they were unsuccessful. This work was a mixed result of success as in the early years the Restora- 
tive City vision had not yet saturated into the wider community and there was little understanding of the benefits of a restorative approach.

Another Council request was to assist with issues coming from large and smelly trucks parking at a motel located in a small community. In this case Council could take no regulatory action as the motel was legally conducting business and yet Council was being accused by residents of its ineffectiveness to stop it. Facilitators were able to bring together the four 'parties' involved: residents, motel, Council and trucking companies. Each 'party' heard and were able to understand the relevant difficulties of the others.

Facilitators have also been involved in taking a restorative approach with family difficulties. These family difficulties were not where serious harm was occurring and so participants were able to respectfully explore with each other their issues and come to an agreement of how to move forward together.

Requests from local organisations range from Government, non-profit or corporate, and have also led to requests from their branches out of Whanganui. Some are keen to resolve conflict between staff when it first emerges and others see a restorative approach as a last resort when all other traditional disciplinary steps have been taken. Each case is unique and dynamic. Wherever requests come from, the Trust's facilitators feel privileged to be invited into opportunities to assist people through conflict. However, that is only one part of the Restorative City vision as it is not only where there are difficulties that facilitators are invited, but in assisting developing respectful relationships to both alleviate conflict and empower people to work through conflict themselves.

\section{Some findings and further perspectives}

The breadth of the vision and a lack of precedent in Australasia meant the beginnings of the Restorative City vision seemed to flounder and there was a period before a loose structure was created to help direct the work of the part time paid co-ordinator. Even with a structure the vision seemed to progress sporadically across the various areas of the city. Coming across the Goodwin Development Trust's research report (Lambert, Johnstone, Green \& Shipley, 2011) helped the Trust identify that the path of implementation for the vision was organic but the challenge would be to manage and evaluate it. Professor Chris Marshall, Diana Unwin Chair in Restorative Justice and the team at Victoria University's School of Government took up the evaluation challenge in 2015 in the form of an appreciative inquiry (findings are yet to be published). ${ }^{3}$

The original idea was to promote the restorative approach to address or transform conflict. This concept was hard to sell because of the negative connotation of the word conflict and a reluctance to admit to problems in workplaces and organisations. Also, as the term 'restorative justice' is well recognised as belonging to the criminal justice system, individuals had the misconception that a

3 Diana Unwin Chair in Restorative Justice, Victoria University, Wellington, New Zealand: www.victoria.ac.nz/sog/researchcentres/chair-in-restorative-justice/research/publications. 
restorative approach was not for them if they were not a victim of crime. The Trust realised it needed to concentrate on the positive aspects of a restorative approach and began work in promoting healthy relationships within workplaces.

This work has its own challenges where some organisations find it difficult to understand the benefits of promoting healthy relationships in their workplace. Some organisational leaders fall back on the misconception that if staff do not like the workplace culture they can leave. Fortunately new guidelines created from New Zealand's revised Health \& Safety Act 2015 includes information to 'build good relationships in a respectful work environment' (WorkSafe New Zealand, 2017). This legislation has been useful as it brings a level of credibility to introducing a restorative approach in reluctant organisations.

Regardless of whether the Trust's approach is addressing conflict or promoting healthy relationships, the sustainability of the vision is the biggest challenge. As restorative justice is sustained through the Ministry of Justice, the Trust has needed to think as a 'social enterprise' to sustain the Restorative City vision. This enables the Trust to broker services for conflict facilitation and/or training and continue to employ a co-ordinator and bring on more facilitators.

The Trust is well aware, that a Restorative City is an aspirational vision and may never be fully realised. The underlying drive to keep working towards the vision emanates from the passion of the Trustees and their determination to make positive changes in the Whanganui community. It is the sometimes difficult, but rewarding conversations, connections and relationships made on the way that affirms they are successfully working towards 'creating the environment for Whanganui people to thrive and succeed together through respectful relationships'.

\section{References}

Lambert, C., Johnstone, G., Green, S. \& Shipley, R. (2011). Building restorative relationships for the workplace (Research Report). Hull: University of Hull.

Downie, J. \& Llewellyn, J.J. (eds.) (2012). Being relational: Reflections on relational theory and health law. Vancouver: UBC Press.

Ministry of Education. (2015). Positive behaviour for learning: 2015 overview. Retrieved from http://pb4l.tki.org.nz/Media/Files/PB4L-2015-Overview (last accessed 5 May 2019).

Ministry of Justice. (2017). Restorative justice: Best practice framework in New Zealand. Retrieved from https://www.justice.govt.nz/assets/Documents/Publications/ restorative-justice-best-practice-framework-2017.pdf (last accessed 5 May 2019).

Whanganui District Council. (2017). Whanganui district council code of conduct. Retrieved from https://www.whanganui.govt.nz/our-council/publications/policies/Documents/ Whanganui\%20District\%20Council\%20Code\%20of\%20Conduct\%202017.pdf (last accessed 5 May 2019).

WorkSafe New Zealand. (2017). Preventing and responding to bullying at work. Retrieved from https://worksafe.govt.nz/topic-and-industry/bullying-prevention-toolbox/goodpractice-guidelines-preventing-and-responding-to-bullying-at-work/ (last accessed 5 May 2019). 